\title{
飽和－不飽和浸透流解析による地下水位の予測と 斜面の安定性評価
}

\author{
Evaluation of groundwater level and slope stability based on \\ numerical analyses of saturated-unsaturated seepage in soil
}

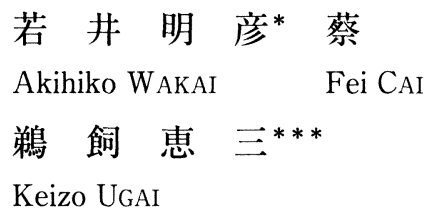

\begin{abstract}
The effects of the horizontal drains on the ground water level are predicted using the three-dimensional finite element analyses of water flow through unsaturated-saturated soils. The slope stability is evaluated by the total factor of safety, using the three-dimensional elasto-plastic finite element analyses based on the shear strength reduction method. In the elasto-plastic analyses, the initial effective stress in the slope is evaluated by the distribution of pore water pressure wich has been given by the seepage flow analyses.

As indicated in this paper, in cases where the horizontal drains are constructed in inappropriate areas in the slope, the improvement of the total factor of safety is not satisfactory. It is confirmed that the analytical method presented in this paper is expected to be very effective for the evaluation of the performance of actual horizontal drains in slopes.
\end{abstract}

キーワード : 斜面安定解析, 浸透, 弾塑性 ${ }^{*}$, 地下水, 不飽和土, 排水ボーリングエ*, 有限要素法

\section{1. はじめに}

降雨や融雪等により浸透した地下水が斜面内の間隙水 圧を上昇させ，地すべりを誘発することが知られている。 このため排水ボーリング工や集水井などの設置により， 地すべり地内の地下水位を低下させる対策工を実施する ことが多い。3 次元的な地下水面形状を把握するために 行われた長期地下水位計測の結果などによると, 排水工 の周囲では極端な水位低下が見られるものの, 排水工か ら離れた位置では水位があまり低下しないことが指摘さ れている（丸山ら（1996）, 曹ら（1998）, 地すべり学会 北海道支部（1999）など）。

一般に各種排水工法の評価は, 地下水位の低下に関し てごく定性的な検討に終始してしまう場合が多い。しか し排水工をより有効な形で設置するためには, 排水効果 が及ぶ具体的な範囲とそれがもたらす斜面の全体安全率 の増加とを適切に評価することが望ましい。亀井ら(1996

* 群馬大学工学部講師, 博 (工)

$* *$ 群馬大学工学部助手, 工修

$* * *$ 群馬大学工学部教授, 工博 b）は土の不飽和浸透特性を考慮した解析によりモデル 斜面内の間隙水圧の挙動を調べている。また 2 次元的に 簡略化した解析ではあるが，集水井の排水効果について も評価している（龟井ら (1996 a))。地下水の解析的研 究は流出解析の分野などでも最近活発化している（例え ば登坂ら（1996））。陸水循環をマクロな視点で捉えた解 析的研究は, 地域防災の観点からもきわめて重要である。 降雨時の斜面のより合理的な設計を実現するため, 鵜 飼ら (1998 a)は降雨時の不飽和浸透流解析により得られ た斜面内各位置の間隙水圧值をもとに, せん断強度低減 法に基づく FEM 解析から斜面の全体安全率を求めてい る。また Cai ら (1998) はこのような解析手法を排水ボー リング工の 3 次元解析に応用し, 降雨時の斜面の安定性 向上に寄与する排水ボーリング工の効果を定量的に評価 している。

以上を受けて，本研究では排水ボーリング工設置によ る斜面内の常時地下水位の変化について検討するととも に，それがもたらす斜面の安定性向上について，弾塑性 FEMにより得られた臨界すべり面の 3 次元的な形状な どを踏まえて考察する。 


\section{2. 解析の方法}

ここでは定式化の概要を示すにとどめ, 詳細は文献(鵜 飼ら $(1998 \mathrm{a}))$ に譲る。

\section{1 飽和一不飽和浸透流解析}

飽和 - 不飽和土中の水の浸透現象に関する支配方程式 は次式で表される。

$$
\nabla \cdot(K(\theta) \nabla(\Phi+z))=c(\theta) \frac{\partial \Phi}{\partial t} .
$$

ここに, $K(\theta)$ は土の透水係数, $\theta$ は体積含水率, $\Phi$ は圧力水頭, $z$ は基準位置からの高さ, $t$ は時間, $c(\theta)$ は比水分容量である。式(1)を離散化してFEMにより解く。 不飽和土の透水係数と比水分容量は体積含水率, 従っ て圧力水頭の関数である。一般にこれらの間の関係は実 験的に決定されるが, 本研究では次式 (van Genuchten (1980))を用いた。

$$
\begin{aligned}
& S_{e}=\frac{\theta-\theta_{r}}{\theta_{s}-\theta_{r}}=\left(1+|\alpha \Phi|^{n}\right)^{-m} \\
& c(\theta)=\alpha(n-1)\left(\theta_{s}-\theta_{r}\right) S_{e}^{1 / m}\left(1-S_{e}^{1 / m}\right)^{m} \\
& K(\theta)=K_{s} K_{r}=K_{s} S_{e}^{1 / 2}\left\{1-\left(1-S_{e}^{1 / m}\right)^{m}\right\}^{2}
\end{aligned}
$$

ここで $S_{e}$ は相対飽和度である。 $\theta_{r}$ と $\theta_{s}$ はそれぞれ残 留及び飽和体積含水率である。 $K_{s}$ と $K_{r}$ は飽和及び相対 透水係数である。 $\alpha, n$ 及び $m$ は定数であり, 経験的に $m=1-1 / n(n>1)$ の関係がある。

\section{2 せん断強度低減法による斜面安定解析}

飽和一不飽和浸透流解析により地盤内の水圧分布が計 算されると, 同じ有限要素メッシュを用いてせん断強度 低減有限要素法により, 時々刻々と変化する斜面の全体 安全率を計算できる。

土のせん断強度はBishop（1959）の提案した係数 $\chi$ を用いて次式により与えられると仮定した。

$$
\tau_{f}=c^{\prime}+\left\{\left(\sigma-u_{a}\right)+\chi\left(u_{a}-u_{w}\right)\right\} \tan \phi^{\prime}
$$

$\tau_{f}$ はせん断強度, $\sigma$ は全垂直応力, $u_{a}$ は間隙空気圧, $u_{w}$ は間隙水圧である。本研究では， $\chi=S_{e}$ と仮定した。

\section{3. 解析対象とした斜面}

解析の対象とした斜面は文献 (Cai ら (1998)) と同一 である。メッシュ分割図を図ー 1 に示す。解析で仮定し た初期地下水位は，それぞれ斜面の上流側（天端後方） ではメッシュ下端から $14 \mathrm{~m}$ ，下流側（法尻前方）では $5 \mathrm{~m}$ とした。また排水ボーリング工は斜面の法尻から斜 面内に水平に設置され，断面の垂直方向に一定間隔 $(2$. $S ） て ゙$ 配置されていると仮定した。排水ボーリング工に 沿って水は完全に排水されると仮定し，排水ボーリング 工の位置にある節点での間隔水圧はゼロとした。

浸透流解析に用いる土質は, 透水係数が比較的小さい 粘土質ローム (Glendale clayey loam：GCL と略記（van
Genuchten (1980)) と, 比較的大きいローム質砂 Bet Degan loamy sand: BLS と略記 (Russo ら (1980))の 2 種類とした。表 -1 にこれらの透水特性を表すパラメー 夕值を, 図- 2 に水分保持曲線を示す。斜面内の初期相 対飽和度は深さ方向に直線的に変化すると仮定した。斜 面法肩での初期水分特性を表 -2 に示す。

一方, 斜面安定解析における土質定数には, GCL と BLSのいずれの場合においても表一 3 の值を用いた。

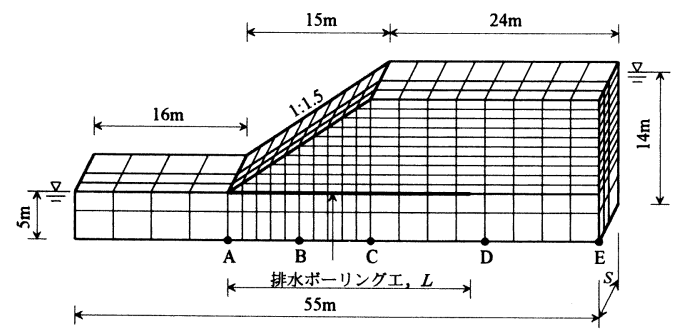

図-1＼cjkstart有限要素メッシュ分割(排水ボーリング工を有する斜面)

表一1 土の透水特性

\begin{tabular}{c|c|c}
\hline & $\begin{array}{c}\text { Glendale clayey loam } \\
\text { (GCL) }\end{array}$ & $\begin{array}{c}\text { Bet Degan loamy sand } \\
\text { (BLS) }\end{array}$ \\
\hline$\alpha\left(\mathrm{m}^{-1}\right)$ & 1.0601 & 2.7610 \\
\hline$n$ & 1.3954 & 3.0224 \\
\hline$\theta_{r}$ & 0.106 & 0.044 \\
\hline$\theta_{s}$ & 0.469 & 0.375 \\
\hline$K_{s}\left(10^{-4} \mathrm{~cm} / \mathrm{s}\right)$ & 1.516 & 63.832 \\
\hline
\end{tabular}
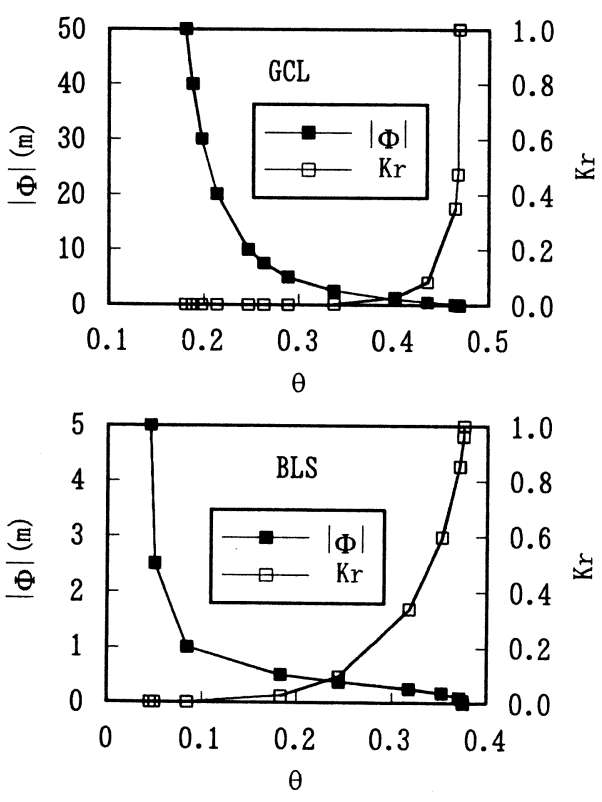

図一2 土の水分保持曲線

表一2 斜面法肩の高さでの初期水分特性

\begin{tabular}{c|c|c}
\hline & $\begin{array}{c}\text { Glendale clayey loam } \\
(\mathrm{GCL})\end{array}$ & $\begin{array}{c}\text { Bet Degan loamy sand } \\
(\mathrm{BLS})\end{array}$ \\
\hline$\theta$ & 0.330 & 0.232 \\
\hline$S_{r}$ & 0.704 & 0.618 \\
\hline$S_{e}$ & 0.617 & 0.617 \\
\hline
\end{tabular}


表ー3 斜面の安定解析に用いた土質定数

\begin{tabular}{c|c}
\hline ヤング率 $E$ & $98.1 \mathrm{MPa}$ \\
\hline ポアソン比 $v$ & 0.3 \\
\hline 単位体積重量 $\gamma$ & $17.66 \mathrm{kN} / \mathrm{m}^{3}$ \\
\hline 有効粘着力 $c^{\prime}$ & $7.85 \mathrm{kPa}$ \\
\hline 有效摩擦角 $\phi^{\prime}$ & $25^{\circ}$ \\
\hline
\end{tabular}

\section{4. 解析結果と考察}

\section{1 排水ボーリングエの効果}

排水ボーリング工設置による斜面内の地下水位の低下 について検討する。図ー3 は排水ボーリング工の無い場 合の定常状態を初期値として, 排水ボーリング工が設置 された場合の斜面内各位置の間隙水圧の経時変化の様子 を示したものである。ここで排水ボーリング工の長さ $L=15 \mathrm{~m}$, 施工間隔 $2 \cdot S=10 \mathrm{~m}$ とした。図中の点 $\mathrm{A} \sim$ $\mathrm{D}$ の斜面内の位置は図ー 1 に示した。

図ー3 から分かるように, 透水性の大きく異なる GCL と BLS とで水圧の変化する速さは異なるものの, 十分 に時間の経過した後（定常状態）においては両者の結果 に差異のないことが分かる。以上より定常状態における 地下水位分布は土の透水係数の大きさには依存しないこ とが確認された。

なお以降の議論では定常状態のみを対象とするため, 透水性の異なる土質を用いても基本的に同一の解析結果

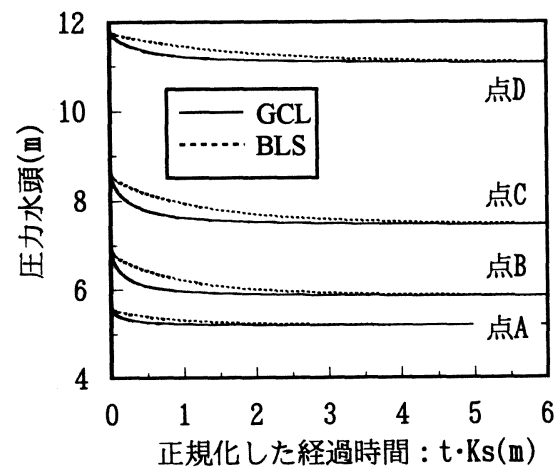

図一3 経過時間と圧力水頭の関係
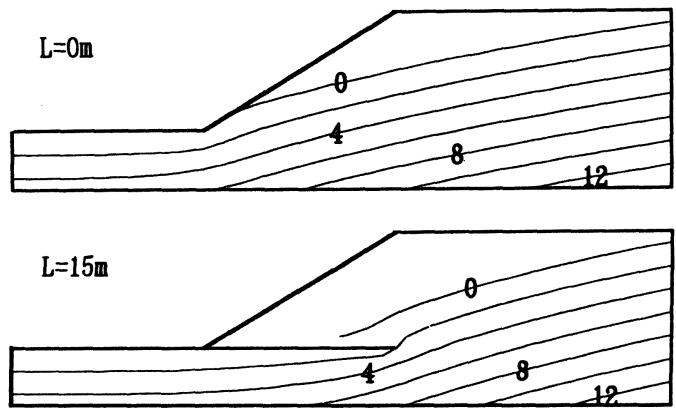

図-4 定常状態での斜面内の水圧分布 (単位 : 水頭 $(\mathrm{m})$ )
が得られる。このため特に断りのない限り GLS や BLS といった土質名称は省略することに注意されたい。

図 -4 に排水ボーリング工の無い場合, 有る場合（図 -3 の最終状態と同じ条件 $; L=15 \mathrm{~m}, 2 \cdot S=10 \mathrm{~m}$ ）の 定常状態の間隙水圧分布を示す。排水ボーリング工の周 囲で地下水位が極端に低下しているのが分かる。地下水 位が低下した部分では有効応力が増加するため, 斜面の 全体安全率は増加していることが予想される。図中で水 圧ゼロの線は地下水位に相当するが，この線の上の領域 は計算上は若干の負圧が発生している。

\section{2 排水ボーリングエの長さの影響}

図 $-5,6$ および図 -8 は排水ボーリング工の長さ $L$ を変化させた場合の定常状態における結果の相違を示し ている。図 -5 は各点の間隙水圧の值, 図-6 はせん断 強度低減法に基づく弾塑性 FEM で得られた斜面の全体 安全率である。弾塑性解析の際に用いる各要素の初期応 力（有効応力）は自重より計算される全応力と, 浸透流 解析で得られた間隙水圧により求めた。ただし間隙水圧 が負の場合は無視してゼロとした。

図ー5，6によると，排水ボーリング工が斜面の奥深 くに達するにつれ，斜面内の間隙水圧すなわち地下水位 も徐々に低下し斜面の全体安全率は増加することが分か る。ただし図ー6から分かるように，排水ボーリング工 の長さが $20 \mathrm{~m}$ 以上になると, それ以上排水ボーリング 工を長くしても斜面の全体安全率の増加はさほど顕著に

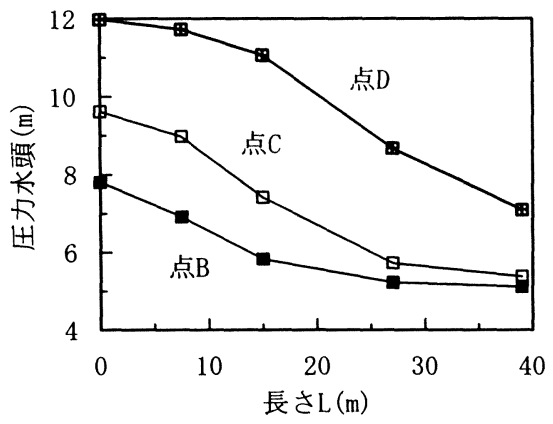

図－5＼cjkstart排水ボーリング工の長さ $L$ と圧力水頭の関係

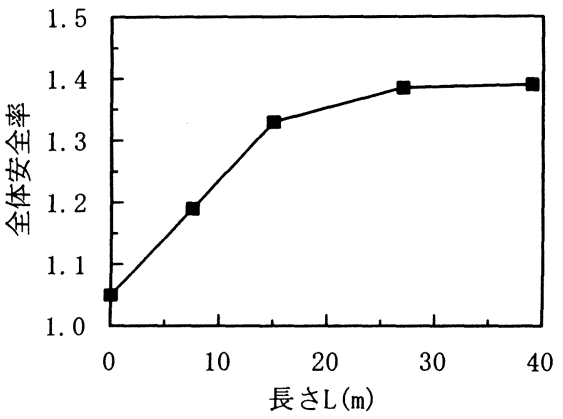

図一6 排水ボーリング工の長さ $L$ と全体安全率の関係 
は見られない。これは斜面の臨界すべり面の位置が斜面 の法尻からおおむね $20 \mathrm{~m}$ 以内に存在することを意味し ており，斜面のすべりに寄与しない部分への排水対策工 は重要でないことを示唆している。

臨界すべり面の位置を確認するため, 全体安全率を求 める際に得られた斜面内の八面体せん断ひずみ $\gamma_{o t}$ の分 布を図ー7に示す。これはせん断強度低隇有限要素法に おける発散 (崩壊) 直前の各要素のひずみ值であり, ひ ずみの大きい部分で特に塑性化が進行していることを意 味する。塑性化が進行した領域が帯状につながり斜面全 体の崩壊機構を形成したものが臨界すべり面に相当する。

本ケースでは排水ボーリング工の有無に関わらず，斜 面内の塑性化領域は法尻からおおむね $20 \mathrm{~m}$ 以内にとど まっていることが確認された。なお剛塑性体を仮定した 極限解析法などの解と異なり，このように破壊に至るま での変形を考虑した弾塑性解析では, 塑性化領域が必ず しも不連続なすべり面を伴わないことに注意されたい。

また図ー7 で示した各ケースのひずみ分布を比較する と, 排水ボーリング工が長くなるにつれて塑性化領域は 相対的に浅い位置に移動することがわかる。排水ボーリ

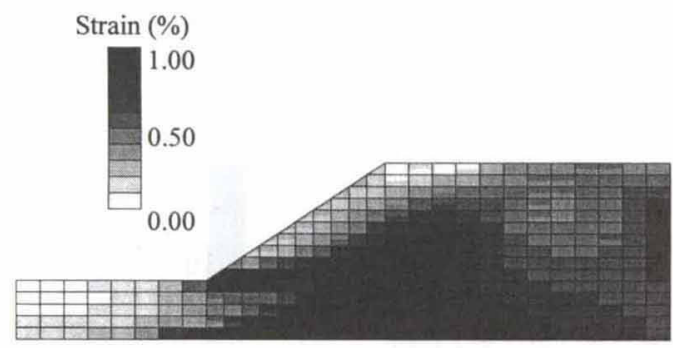

(a) 排水ボーリングエなし
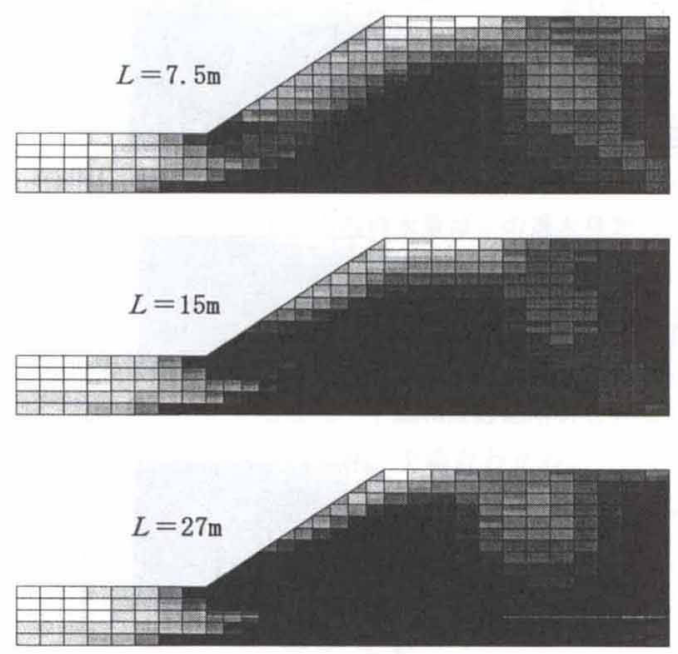

（b）排水ボーリング工あり（長さ $L$ )

図ー7 せん断强度低減法による崩壊直前の八面体せん断 ひずみ $\gamma_{\alpha c t}$ の分布 (排水ボーリンク工の長さ $L$ を変化)
ング工の設置は斜面内の有効拘束圧の増加に寄与するた め, 排水が良好なケースほど，より拘束圧の大きな地盤 深部の強度を增加させる結果となる。これは $\phi$ 材で臨 界すべり面がより浅い位置に表われることと力学的に一 致している。

図ー8 は GCL およびBLS を用いた場合の, 排水ボー リング工からの排水量の比較である。図 $-5,6$ と同様 に排水ボーリング工の長さを変化させた一連のケースに ついてプロットした。排水量 $Q$ を土の飽和透水係数 $K$ で除いた值を縦軸にとると，GCL と BLS とで結果に差 異のないことが分かる。これは排水ボーリング工からの 排水量が土の $K$ に比例すると同時に, 他の透水パラ メータには依存しないことを意味する。

排水量 $Q$ と飽和透水係数 $K s$ との関係は, 排水ボー リング工の間隔を変化させた場合（次節参照）について も同様の傾向が見られるが本論文では省略する。

\section{3 排水ボーリングエの間隔の影響}

次に排水ボーリング工の間隔を変化させた場合の一連 の解析結果について, 前節と同様に定常状態に着目して 議論する。図 -9 は排水ボーリング工の長さ $L$ が $7.5 \mathrm{~m}$ と $15 \mathrm{~m}$ のそれぞれの場合において, 間隔 $S$ が変化した 時の斜面の全体安全率の值を示したものである。間隔が 広くなるにつれて斜面の全体安全率は徐々に低下するが, 排水ボーリング工の長さの影響に比べればその影響はあ

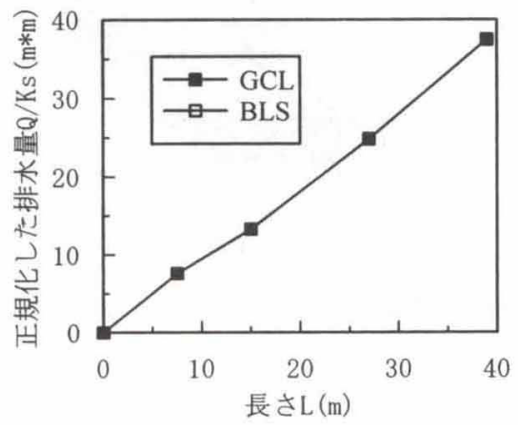

図-8 排水ボーリング工の長さ $L$ と 排水ボーリング工からの排水量の関係

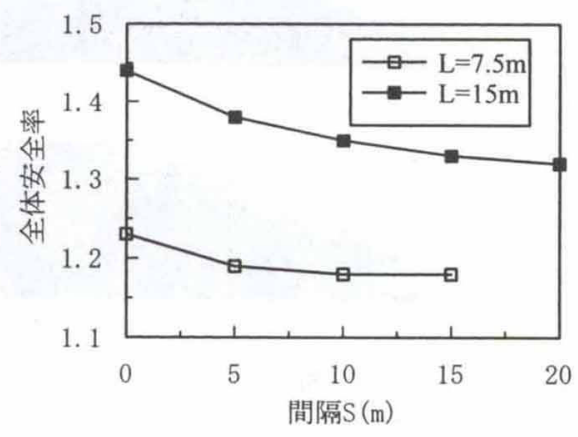

図一9 排水ボーリング工の間隔 $S$ と全体安全率の関係 
まり顕著ではないことが分かる。これは間隔がある程度 広くなっても, 排水ボーリング工近傍の有効応力の大き い領域が斜面崩壊に対して卓越した抵抗力を発揮するこ とを示している。

図ー 10 は図 -7 と同様にせん断強度低減法により全体 安全率を算出した際の, 崩壊直前の八面体せん断ひずみ 分布を示したものである。排水ボーリング工のある断面 （断面 A）および排水ボーリング工同士の中間位置の断 面（断面 B）について，排水ボーリンクエの間隔 $S$ の 異なる各ケースの結果をそれぞれ示した。なお $S=0$ は 排水ボーリング工が奥行き方向に連続的（間隔なし）に 続く場合を想定した二次元解析の結果である。

断面 $\mathrm{A}$ では排水ボーリング工の間隔が狭くなるにつ れて，ひずみの大きな領域が相対的に浅い位置に移動す ることがわかる。これは図 -7 で排水ボーリング工のよ り長いケースで見られた傾向と類似している。一方, 断 面 B のひずみ值は断面 $\mathrm{A}$ のものより全般的に大きめで あるが，分布性状については断面 $\mathrm{A}$ のものに近い。す なわち斜面の臨界すべり面は排水ボーリング工の間隔に よらず奥行き方向にほぼ同一の形状となることがわかる。

\section{4 三本組みの排水ボーリングエの方向角の影響}

実際には排水ボーリング工が一本単独で設置されるこ
とは少ない。ここでは図ー11のメッシュ図（排水ポー リング工のある断面の平面図）に示すように, 方向角で 互いに $\alpha$ の違いを有する三本組みの排水ボーリング工 （長さは三本とも $L$ ) の効果について検討する。なお解 析では系の対称性を利用して, 排水ポーリング工一本半 を含む領域を対象とすることに注意されたい。

$L=7.5 \mathrm{~m}, S=7.5 \mathrm{~m}$ および $L=15 \mathrm{~m}, S=15 \mathrm{~m}$ の それぞれの場合について, 方向角 $\alpha$ を変えた時の各点 の間隙水圧の值（定常状態）を図-12に示す。方向角 の影響はさほど顕著ではない。排水ボーリング工のより 長いケース $(L=15 \mathrm{~m}, S=15 \mathrm{~m})$ において, $\alpha=30^{\circ}$ 前後で水圧の極小值が見られる。これは $\alpha$ が小さ過ぎ ると排水ボーリング工一本の場合と同程度の排水効果し か得られないのに対して, 逆に $\alpha$ が大き過ぎると斜面 のより奥の位置にまで排水ボーリング工が届かないこと から,やはり排水効果が低下してしまうことを示してい る。以上の効果が排水ボーリング工のより長いケースで 特に現れたのは, 排水距離が長いほど間隙水圧の消散す る速度が場所ごとに大きく異なるためと考えられる。

以上, 典型的な例題を通して, 斜面内の定常水位と排 水ボーリング工との関係, また斜面の全体安全率への影 響について述べてきた。このような解析手法により，実
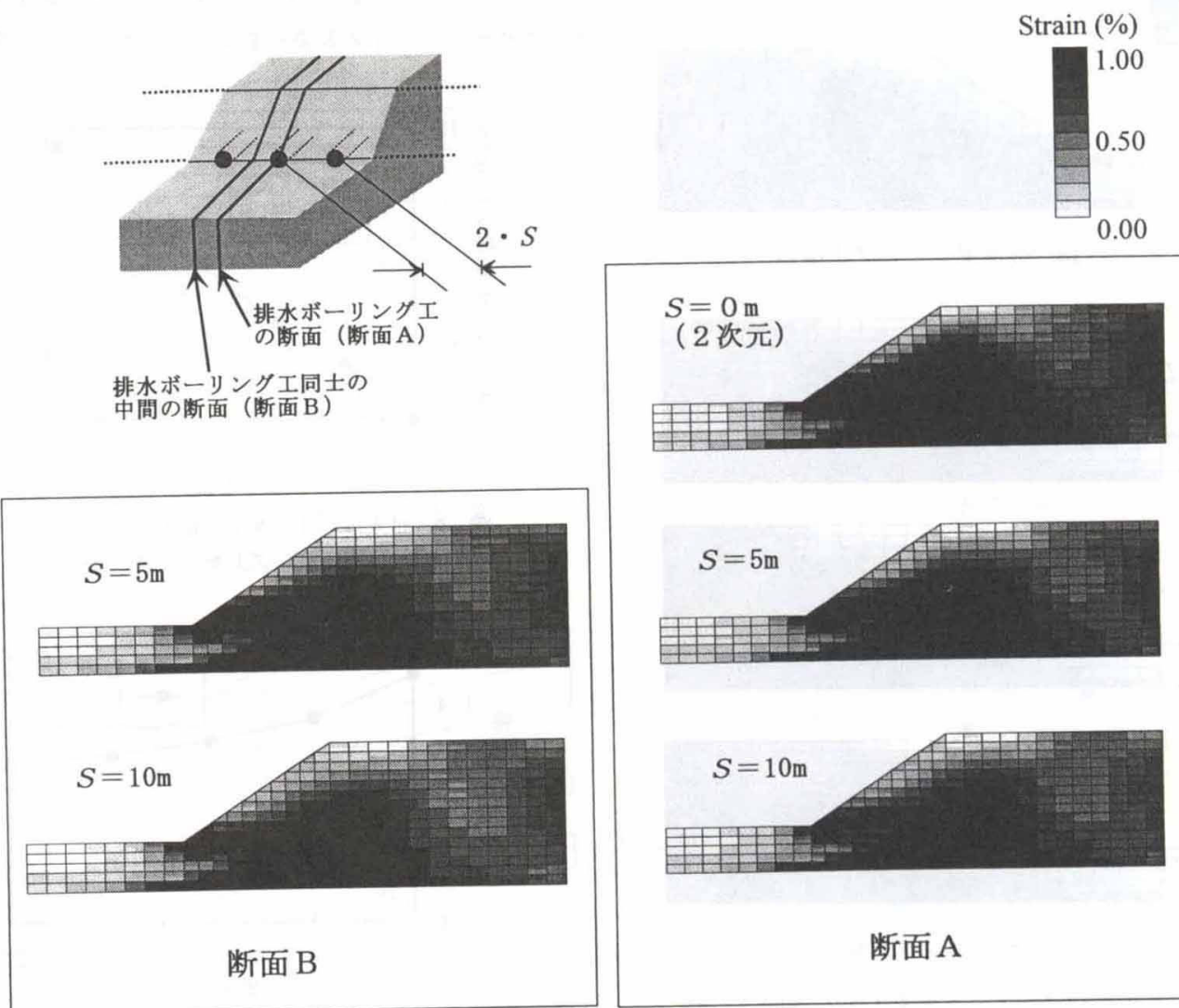

断面 A

図一10 せん断強度低減法による崩壊直前の八面体せん断ひする 


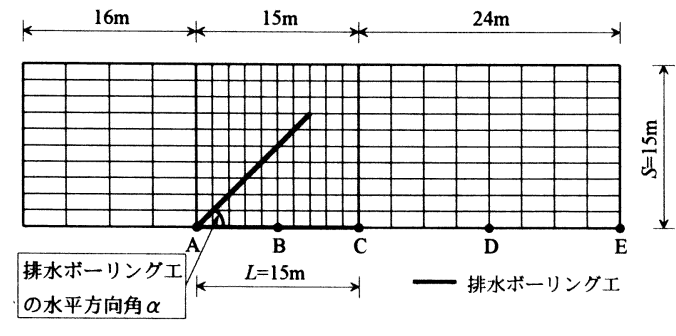

図-11 有限要素メッシュの平面図 （3 本組の排水ボーリング工を有する斜面）

際の排水ボーリング工の長さや設置する位置, 方向, 間 隔などに対して, 合理的な指針を与えることが可能であ る。また地すべり地内の 3 次元的な地層構成を考慮（各 種土質定数を把握) することで, 3 次元的な地下水位分 布と 3 次元的な力の釣合いに基づいた，より適切な斜面 の全体安全率の算定が可能となる。実際の設計業務にお ける応用が期待される。

\section{5. まとめ}

本研究により得られた知見をまとめると以下のとおり である。

（1）斜面内の定常状態における地下水位分布は土の透水 性には依存しないことが確認された。

（2）排水ボーリング工の周囲では地下水位が低下して有 効拘束圧が増加する。斜面の安定性を高めるには, 斜面の臨界すべり面付近の水圧を十分に低減させる ような排水ボーリング工が有効である。

(3) 排水ボーリング工の長さと間隔を変えた一連の解析 から，排水ボーリング工の間隔を狭くするより，長 さを十分に長くした方が, 斜面の安定性向上に有効 であることが分かった。

（4）排水ボーリング工が長くなるにつれて，また間隔が 狭くなるにつれて, 斜面の臨界すべり面位置は相対 的に浅い位置に移動する。

（5）排水ボーリング工からの排水量は土の透水係数に比 例すると同時に，他のパラメータには依存しない。

(6) 斜面の臨界すべり面は排水ボーリング工の間隔によ らず奥行き方向にほぼ同一の形状となる。

（7）有限要素法による飽和一不飽和浸透流解析と弾塑性 解析（せん断強度低隇法）を組合わせることで， 3 次元的な地下水分布や土の強度分布に基づいた適切 な斜面の全体安全率の算定が可能となる。

\section{参考文献}

Bishop, A. W. (1959) : The principle of effective stress, Publication 32, Norwegian Geotechnical Institute, Oslo, pp. 14.

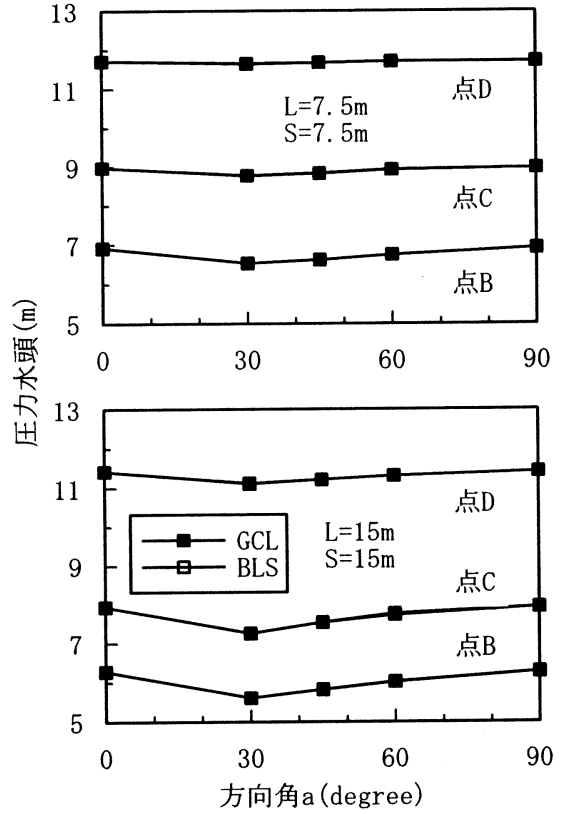

図-12 排水ボーリング工の方向と圧力水頭の関係

Cai, F., Ugai, K., Wakai, A. and Li, Q. (1998) : Effects of horizontal drains on slope stability under rainfall by threedimensional finite element analysis, Computers and Geotechnics, Vol. 23, pp. 255-275.

Cai, F. and Ugai, K. (1999): Effects of horizontal drains on ground water level and slope stability, Int. Symp. on Slope Stability Engineering, IS-SHIKOKU '99, Matsuyama, Japan (to be published).

Genuchten, M. T. (1980) : A closed-form equation for predicting the hydraulic conductivity of unsaturated soils, Soils Science Society of America Journal, Vol. 44, pp. 892 -898 .

地すべり学会北海道支部技術小委員会（1999）：北海道にお ける地すべり対策工の最近の動向, 地すべり, Vol. 35, No. 4, pp. 43-50.

亀井健史・榎本雅夫（1996 a）：飽和一不飽和浸透流解析に よる集水井工の評価，地すべり，Vol. 33，No.1，pp.5359.

亀井健史・榎本雅夫（1996 b）：降雨および地下水流が斜面 内の間隙水圧挙動に及ぼす影響, 地すべり, Vol. 33, No. 2, pp. $10-16$.

丸山清輝・北島義則（1996）：地すべり地における集水井の 地下水排除効果に関する検討, 地すべり, Vol. 33, No. 3, pp. $13-18$.

Russo, D. and Bresler, E. (1980) : Field determination of soil hydraulic properties, Water Resources Research, Vol. 24, pp. $453-459$.

曹崇銘・太田猛彦 - 竹内美次 - 松浦純生 - 落合博貴 (1998)： 集水井集水工法によるすべり面付近の間隙水圧の変動特性 一埼玉県児玉郡児玉町平沢地すべり地を例としてー, 地す ベり, Vol.35, No.3, pp. 24-33.

登坂博行・小島圭二・主章生・千野剛司（1996）：地表流 と地下水流とを結合した 3 次元陸水シミュレーション手法 の開発，地下水学会誌, Vol. 38, No. 4, pp. 253-267.

鵜飼恵三・蔡飛・阪上最一・若井明彦 $(1998 \mathrm{a})$ ：降雨時の 斜面安定性の全体安全率による評価, 地すべり, Vol. 35, No. 1 , pp. $19-23$.

鵜飼恵三・蔡飛・阪上最一・若井明彦 $(1998 \mathrm{~b})$ ：集水ボー リング工の効果に関する定量的評価手法の提案，地すべり， Vol. 35, No. 3, pp. 1-7.

（原稿受理日 平成 11 年 10 月 6 日） 